\title{
Censorship in the PSL Press within the Period of the 1946 Referendum and the Legislative Sejm Election
}

\section{Introduction}

The subject of this article are the activities of censorship authorities of the Polish People's Party (PSL) towards the press within the period prior to the referendum of 30 June 1946 and up to the election for the the Legislative Sejm of 19 January 1947. The time frame is between the 27 April 1946 the passing of the people's voting act by the State National Council (KRN), and the 8 February 1947 of the Sejm's approval of the government of Józef Cyrankiewicz. I analysed material developed by the Main Office of Control of Press, Publications and Shows (GUKPPiW) and its regional divisions ${ }^{1}$. I included documents confirming censor interventions in articles raising the issues associated with the conducting of both electoral actions. Archival material of the PSL stored in the Archiwum Zakładu Historii Ruchu Ludowego - AZHRL (Archive of the Historical Institution of the Peasant Movement) also served as the basis for establishing the facts. A considerable amount of information can be obtained for research into censorship interventions in the PSL press from a collection of all issues of "Komunikat", an internal bulletin of the PSL from 1946-19472, published by the Museum of the History of the Polish Peasant Movement. The periodical, because of its special form of writing addressed only to the PSL members, was not subject to censorship. "Komunikat" also included material halted by censorship in other press outlets.

* Dr, e-mail: piotr_swacha@sggw.pl; Warsaw University of Life Sciences, Chair of Political Sciences and International Relations, Department of Sociology, Faculty of Sociology, 02-787 Warsaw, ul. Nowoursynowska 166.

${ }^{1}$ To learn more about the organisation of the censorship institution in the years following WWII see: K. Kamińska, Początki cenzury, in: Zwrot polityczny '48. Między polska droga a projektem uniwersalnym, M. Jabłonowski, W. Jakubowski, T. Krawczak (eds.), Warsaw 2013, pp. $225-235$.

${ }^{2}$ Komunikaty Polskiego Stronnictwa Ludowego 1946-1947, M. Adamczyk, J. Gmitruk, J. Mazurek (eds.), Warsaw 2002. 
The people's vote of 30 June 1946 and the election for the Legislative Sejm held on 19 January 1947 constituted one of the most important political events leading to the seizure and consolidation of power by Polish communists. Both events were closely interconnected in terms of legal issues, propaganda and politics. As a result of the official results of the referendum ${ }^{3}$ the Higher House of the Parliament was eliminated, thus limiting the legislative power to only the Sejm. The referendum and the election were also aimed at creating a pretence of legitimisation of the rule of the workers' party in Poland. They also served as the basis for excluding the PSL from the formal coalition of the Provisional Government of National Unity (TRJN) and prompted the process of first neutralising and finally breaking up the group ${ }^{4}$.

In the people's vote, the citizens were asked three questions regarding the abolishment of the Higher House of the Parliament, economic and territorial issues $^{5}$. The main propaganda goal behind the referendum was to try to convince the PSL authorities to assume a position on the posed questions in line with the stipulations of the communist party and its satellites. As conceived by the PPR, the referendum was only a provisional form of expression of the society which could later on be considered as an expression of support and trust on the part of the citizens in the new authorities ${ }^{6}$. Eventually, the PSL decided to campaign for keeping the Senate in the system of legislative institutions ${ }^{7}$, which considering the referendum questions was the only way of differentiating its position from the stipulations of the other groups.

The political reason behind the People's Vote was the intention to postpone the parliamentary election. The communists intended elections to become a ritual in which citizens would sanction the pre-established division of seats in the

${ }^{3}$ Both the results of the People's Vote and the election of 1947 were falsified to the benefit of the Polish Workers' Party (PPR) and its allies. To learn more see: Referendum z 30 czerwca $1946 r$. Przebieg i wyniki, A. Paczkowski (ed.), Warsaw 1993, pp. 8-9; M. Skoczylas, Wybory do Sejmu Ustawodawczego z 19 stycznia 1947 r. w świetle skarg ludności, Warsaw 2003, p. 11.

${ }^{4}$ The Polish People's Party existed as a separate party until 27 November 1949 when as a result of merging the PSL with the People's Party the United People's Party (ZSL) formed. Actually, the symbolic date of the end of independent activity of the PSL was 21 October 1947, when Stanisław Mikołajczyk secretly left Poland. To learn more about the PSL after 1947 see: T. Skrzyński, "Wejście” do ZSL. Miejsce na scenie politycznej i losy "Odrodzonego" Polskiego Stronnictwa Ludowego w 1948 i 1949 r., in: Wieś i ruch ludowy w Polsce i Europie, vol. $1 \mathrm{~W}$ kręgu historii i tradycji, J. Gmitruk, A. Indraszczyk (eds.), Warsaw 2012, pp. 533-546.

${ }^{5}$ The questions read as follows: Are you for abolishing the Senate? Do you want the future constitution to establish the economic system introduced by the agricultural reform and the basic sectors of national economy maintaining the basic rights of private initiative? Do you want the western borders on the Baltic, the Oder and the Nysa Łużycka to be established?; People's Vote Act of 27 April 1946, "Journal of Laws of the Republic of Poland", 10 May 1946, No. 15, p. 189.

${ }^{6}$ R. Buczek, Stanistaw Mikołajczyk, vol. 2, Toronto 1996, p. 63.

${ }^{7}$ R. Turkowski, PSL w obronie demokracji 1945-1949, Warsaw 1992, p. 139. 
$\mathrm{Sejm}^{8}$. However, the PSL authorities did not agree to the proposals of the PPR and created a separate electoral list. As a result, during secret meetings of the PPR and the PPS (Polish Socialist Party), it was decided to once again postpone the parliamentary election by replacing it with a referendum. That enabled communists to verify the level of effectiveness of the propaganda machine and the readiness of security officers for the operation of forging votes. It also enabled them to probe the reactions of the Western world to fraud and offered a general breakdown of the atmosphere and political preferences of the Polish society'.

\section{Publication resources of the PSL}

The operation of their own press constituted the basis of propaganda operations for political groups which were reactivated after WWII. That was because it was the most available and the most common medium of mass communication. The political press was also used to transmit party directives, thus serving an organisational function.

In the period prior to the people's vote and the election of the Legislative Sejm, the Polish People's Party was the publisher of seven periodicals, including one daily newspaper, three monthly magazines, two weekly magazines and one periodical, issues of which were initially published every seven days and then three times a week. The first periodical reactivated after 1945 associated with the peasant movement was "Polska Ludowa", managed by Stanisław Mikołajczyk and published by the Greater Poland organisations of the PSL ${ }^{10}$. However, it was "Gazeta Ludowa" that was considered the most important periodical of the PSL, which was published beginning in the autumn of 1945 in Warsaw. It was the only daily newspaper of the PSL and had the highest circulation, which in 1946 reached 125,000 copies.

Within the studied period, one periodical associated with the independent peasant movement was closed by the Chief Executive Committee of the PSL (NKW PSL). It was the "Chłopski Świat" monthly whose editor-in-chief was

\footnotetext{
${ }^{8}$ The authorities of the Polish Workers' Party stipulated the following distribution of votes: $20 \%$ for the PPS, the PPR, the PSL, and the SL each and 10\% for the Alliance of Democrats (SD) and the Labour Party (SP) each while the PSL postulated that $75 \%$ of seats should be assigned to people's parties. Vide R. Turkowski, Polskie Stronnictwo Ludowe..., pp. 124-127.

9 To learn more see: Janusz Wrona, Jedni głosuja a drudzy obliczaja głosy: wybory do Sejmu Ustawodawczego RP w 1947 r., "Annales Universitatis Mariae Curie-Skłodowska. Sectio F. Historia 1997/1998”, vol. LII/LIII, pp. 442-446.

${ }^{10}$ G. Kubicka, Czasopisma regionalne ruchu ludowego w latach 1944-1949, "Kwartalnik Historii Prasy Polskiej”, 1986, issue 3, p. 100; To learn more about the peasant movement organisations in Greater Poland see: P. Swacha, Polskie Stronnictwo Ludowe w Wielkopolsce (1945-1947), "Społeczeństwo i Polityka" 2011, issue 4, pp. 24-39.
} 
Józef Niećka. The stern decision of the PSL's authorities was forced by the criticism published in the periodical of the PSL's decision not to join the electoral bloc $^{11}$. It was the only such event within the period from the start of the referendum campaign until 8 February 1947.

Titles of the PSL periodicals with circulation in 1946 and 1947 are presented in Table 1.

Table 1. Circulation of the press of the independent peasant movement in 1946-1947

\begin{tabular}{|c|c|c|c|}
\hline \multirow{2}{*}{ Title } & \multirow{2}{*}{ Type } & \multicolumn{2}{|c|}{ Circulation in thousands of copies } \\
\cline { 3 - 4 } & we46 & $\mathbf{1 9 4 7}$ \\
\hline "Polska Ludowa" & $\begin{array}{c}\text { weekly, later issued } \\
\text { 3 times a week }\end{array}$ & $25-39$ & $21.5-35$ \\
\hline $\begin{array}{c}\text { "Chłopski } \\
\text { "Sztandar" }\end{array}$ & weekly & $37-50$ & No information \\
\hline "Piast" & weekly & $20-35$ & 33 \\
\hline "Gazeta ludowa" & daily & $45-125$ & 75 \\
\hline "Wieś i Państwo" & monthly & 4 & 4 \\
\hline "Chłopski Świat" & monthly & 10 & No information \\
\hline "Przebudowa" & monthly & No information & No information \\
\hline
\end{tabular}

Source: P. Swacha, Polityka informacyjna Polskiego Stronnictwa Ludowego (1945-1947), Warsaw 2010, pp. 115-129.

Available data enabled me to establish the circulation of the majority of periodicals published by the PSL. Within the studied period the number of single-time issues was gradually lowered starting from the beginning of 1947. It was associated with the consistent limiting by the secret service of the publishing potential of the PSL managed by Stanisław Mikołajczyk ${ }^{12}$.

\section{Quantitative analysis of interventions}

The currently available source material makes precise comprehensive quantitative analysis of censor interventions in the periodicals of the independent peasant movement impossible. It is mainly a result of a temporary release

${ }^{11}$ S. Stępień, Prasa ludowa w Polsce. Zarys historyczny, Warsaw 1984, p. 129.

12 The fight against the press and campaigning activities of the PSL also assumed the form of physical repression and organising political court trials against the journalists and employees of the Press and Propaganda Division of the PSL. To learn more see P. Swacha, Polityka informacyjna ..., pp. 79-80. 
exclusion of GUKPPiW documents by the Archive of New Records. Therefore, in order to conduct a quantitative analysis estimation of content regulated in the PSL periodicals, I decided to use a sample in the form of interventions in Polska Ludowa published by the Voivodship Board of the PSL in Poznań. The reason behind the decision was the availability of the source material: reports on censorship inspections in Polska Ludowa are made available by the State Archive in Poznań; it can also be considered as an organised and complete collection. The periodical has been chosen as a sample also because it was published without any interruptions within the studied period; from January 1946 it was published three times a week, and in the period prior to the people's vote and the election to the Legislative Sejm it had a circulation close to the average of PSL periodicals. Moreover, the political content published in the PSL periodicals were not a result of free actions by their editorial boards. The periodicals of the peasant movement managed by Stanisław Mikołajczyk were subject to the Press Department which was part of the Press and Propaganda Division of NKW PSL. Its main task was to, i.a. "maintain the political line of all periodicals associated with the Peasant Movement". 13

Apart from similarities in the content published in the PSL periodicals, the decision to use such a sample can be further justified by the expected unanimity among the censors regarding articles submitted for inspection. In their operations, censors, regardless of their location, operated on the basis of the same instructions and guidelines sent from Warsaw. Therefore, it must be assumed that during the inspection of political content in periodicals of the same party they should proceed identically.

The number of interventions in individual thematic categories was not equal to the number of articles in which deletions were applied. That was a result of the fact that in some texts certain expressions which applied to various topics were removed. In a single article there could be deletions of both fragments regarding the repressions used against the PSL members and themes associated with election campaigning. When assigning a specific fragment to a specific thematic category I considered censor intervention justifications which were placed in the majority of instances underneath a specific press clipping ${ }^{14}$. The summary includes only texts related to the referendum and the election to the Legislative Sejm which were submitted for inspection within the studied period. Detailed information is presented in Table 2.

${ }^{13}$ Archiwum Zakładu Historii Ruchu Ludowego (AZHRL), PSL 1945-1949, Organizacja Sekretariatu Naczelnego PSL, ref. no. 64, Pismo sekretarza naczelnego do kierownika Wydziału Prawnego Józefa Fabijańskiego, 1. 3.

${ }^{14}$ Those justifications constituted a part of the reports and were meant for the supervisors. 
Table 2. Thematic categories of censor interventions in Polska Ludowa within the studied period

\begin{tabular}{|l|c|}
\hline \multicolumn{1}{|c|}{ Category } & Number of interventions \\
\hline Electioneering and conducting election campaign & 3 \\
\hline Repressions against PSL activists & 12 \\
\hline Method of organisation the referendum and election & 6 \\
\hline Instructions for voters & 6 \\
\hline Legal provisions & 3 \\
\hline Election protests & 12 \\
\hline Forging of votes & $\mathbf{5 3}$ \\
\hline In total: & \\
\hline
\end{tabular}

Source: Own work based on archival material

Within the total number of 53 interventions in the contents of articles of "Polska Ludowa" raising the issues of the people's vote and the election to the Legislative Sejm, the largest group constituted deletions of remarks regarding repressions towards the PSL activists and forging votes. Almost as often censors removed from print fragments presenting information on the organisation of both acts of voting. That meant that censorship intervened to a lesser extent in themes associated with the PSL's campaigning than in texts which could disturb the image of normal political rivalry created by the propaganda.

\section{Qualitative specification of censor interventions}

In terms of qualitative analysis of censor interventions in the PSL periodicals, I used a simplified division into four main thematic categories based on the problem areas raised by the removed fragments ${ }^{15}$. The first applied to issues associated with the mode of preparing both electoral acts and the possibility of controlling their courses. The second included articles of a campaign nature which expressed the position of a group and encouraged citizens to vote for the PSL. The third applied to the repressions used against the activists of the PSL managed by

${ }^{15}$ I based the qualitative analysis on wider source material than the qualitative analysis. I used, e.g. reports (collected before the GUKPPiW collection was excluded from releasing) on censorship in "Gazeta ludowa" and other published documents. 
Stanisław Mikołajczyk who were engaged in conducting the election campaign. The fourth consisted of attempts to inform the population on irregularities and filed protests.

Before the referendum and the election to the Sejm, the PSL tried to undertake several press initiatives aimed at informing the general population on the methods of organising both events. The first initiative which could be included in this category was the attempt to raise the topic of the date of the election. Pursuant to the provisions of the conference in Yalta the election was supposed to be held as soon as possible ${ }^{16}$. In order to ensure a win communists tried to postpone it as much as possible. Based on their Hungarian experience ${ }^{17}$, their goal was to develop the security machine and prepare other party and state institutions to forge votes. Therefore, the issue of the date of the election became an inconvenient topic for the "new rule", consistently being removed from legally published periodicals. People's parties did not attempt any direct presentation of the reasons for the communists' postponing of the election, and yet any mention of the issue exceeding the official position of the PPR in that matter was removed. One instance of such activities were the interventions in the article entitled "Konieczność szybkich wyborów" [The necessity for prompt election] submitted for publication in the Greater Poland periodical of the PSL. Its author tried to state an opinion that a lack of clear political decisions creates a sense of temporariness and a lack of stability, which in turn lead to the formation of social pathology. The censor decided that "the lead idea of the article is murky and beguiling"18 and excluded it from printing in its entirety.

Within the context of preparing for both acts of voting, any reports on the compositions of election committees were consistently being removed. Eliminating such information enabled the party-state propaganda to create an image of a routine electoral rivalry. An example of a typical operation of censorship, which not only removed certain content but also led to manipulating the meaning of the entire text, were the interventions in the article entitled "Ordynacja wyborcza do Sejmu" [Electoral system for the Sejm]. It included an announcement that KRN shall accept the legal regulations regarding the election and a statement of the

\footnotetext{
${ }^{16}$ Komunikat z konferencji szefów rządów Trzech Wielkich Mocarstw, tzw. Konferencji Krymskiej, in: Historia powszechna 1919-1991. Wybór tekstów źródłowych, L. Mularska-Andziak (ed.), Pułtusk 1997, p. 95.

${ }^{17}$ The parliamentary election in Hungary was held on 4 November 1945. It was won by the Independent Smallholders Party (FKgP), which was considered as occupying the same stream of the peasant movement as the PSL. The event complicated the seizure of power by communists in Hungary. To learn more about FKgP see: M. Földesi, K. Szerencsés, Historyczna rola partii chłopskich na Wegrzech po II wojnie światowej, in: Dzieje partii i stronnictw chłopskich w Europie, vol. 2, W podzielonej Europie, Pułtusk-Warsaw, pp. 123-130.

${ }^{18}$ State Archive in Poznań (APP), WUKPPiW, ref. no. 140, Sprawozdania z ingerencji dotyczących Polski Ludowej, 1. 41.
} 
PSL's expectations. Censors approved for publication an opinion stating that commissions of various levels should be composed of representatives of all groups but they removed a fragment which could have suggested that such a regulation shall not be implemented and it will not be applied during the referendum ${ }^{19}$. Thus, the readers, unaware of the stated concerns, could had assumed that the postulated solutions would be accepted.

Censorship not only prevented the propagation of information on the acceptance in the electoral system of provisions limiting the control over the course of the election but also tried to block any information on voter rights. The knowledge of electoral provisions could eliminate the possibility of introducing irregularities or could enable the PSL to gather information on those irregularities. Therefore, e.g. in "Chłopski Sztandar" censors removed a fragment of an article encouraging the readers to read the applicable Polish laws, particularly the "provisions of the Penal Code, which are associated with elections" ${ }^{20}$. In that context, censorship undertook a special "fight" against texts referring to the secret nature of voting. It was a response to the operation of the PPR and its allies of promoting demonstrative and overt voting for bloc parties. Since it exceeded regular display of support for those groups and their main goal was to exert influence or even force people to vote for communists, the PSL tried to inform people about their right to cast their votes in a secret ballot. According to the argument in one of the articles eventually removed in its entirety: "no one can demand voters to vote overtly, to show their ballots to the chairman of the committee before placing them in the official envelope as it is already being promoted in some regional commissions. That constitutes electoral abuse which is subject to prosecution"21. PSL periodicals also attempted to limit the possibility of exerting direct pressure on citizens who would visit the polling stations. Journalists of the Party managed by Stanisław Mikołajczyk seeing the help of uniformed services in conducting the campaign by the bloc parties wanted to draw the readers' attention to the fact that during the vote no representatives of Milicja Obywatelska [the police] or any other state power ministries were allowed to be present in the stations. There were two attempts at conveying that piece of information, once in a quite unique form. Voices indicating the possibility of such instances were presented as baseless gossip spread by the "enemies of the People's Republic" 22 . Even though the

\footnotetext{
${ }^{19}$ APP, WUKPPiW, ref. no. 142, Ingerencje dotyczące gazety "Polska Ludowa", 1. 22.

${ }^{20}$ Annex 19: "Do Generalnego Komisarza Wyborczego", in: Dokumenty fatszerstw wyborczych w Polsce w roku 1947. Drugi memoriał Polskiego Stronnictwa Ludowego w sprawie wyborów w Polsce złożony z załącznikami w dniu 18 I 1947 roku Ambasadorom Stanów Zjednoczonych, Wielkiej Brytanii i Związku Radzieckiego w Warszawie, M. Adamczyk and J. Gmitruk (eds.), Warsaw 2002, pp. 94-95.

${ }^{21}$ AAP, WUKPPiW, ref. no. 143, Ingerencje dotyczące gazety "Polska Ludowa", 1. 1.

${ }^{22}$ AAP, WUKPPiW, ref. no. 141, Ingerencje dotyczące gazety "Polska Ludowa", 1. 75.
} 
text emulated the party-state propaganda discourse, censorship halted it. Probably because even the fact of mentioning the issue was considered unfavourable for the ruling party.

In the context of the organisation of the election, the PSL periodicals also tried to inform the readers about the accepted procedural solutions which could have caused confusion among the supporters of the peasant movement. One example was the process of assigning the PSL different electoral list numbers in every district. Censorship banned any comments about it, allowing for only the announcement of the PSL's electoral lists in individual regions of the country. Accordingly, censors removed any suggestions indicating that it was not accidental ${ }^{23}$ or reminding that similar situations occurred during the pre-WWII elections ${ }^{24}$. They also banned any information about the distribution of ballots, which could have resulted in the PSL's sympathisers casting invalid votes. That was associated with the accepted form of voting. Citizens received at polling stations only stamped envelopes into which they had to put a ballot with a personally entered number from a given list. Before the election, there were ballots being distributed which included the PSL's electoral list number, similar to those created by the party, but with an invalid imprint. An attempt to warn against using them was blocked by censorship ${ }^{25}$.

During the initial months after the formation of the Provisional Government of National Unity, one of the tasks of censorship was to protect the propagandacreated image of a political system in which the official discourse was presented as democratic. Therefore, any information which could have indicated the existence of any persecutions of the representatives of legally operating political parties were removed from the press. The removal of content related to repression against the opposition constituted an element of the general strategy of eliminating any information indicating a lack of political liberties in the post-WWII Poland, but those activities were intensified considerably around the time of the referendum and the election, when censor decided to remove several articles in their entirety, which was a rare practice, even considering the institution's restrictive disposition towards the PSL periodicals. Such actions were taken against texts which directly reported on the situation. For example, the censors removed from "Gazeta Ludowa" such articles as: "Rzeczywistość przedwyborcza w Polsce. Represje wobec PSL" [Pre-election reality in Poland. Repressions against the PSL], "Aresztowania przedwyborcze wzmogły się. Wiadomości nadesłane z Krakowa i Poznania" [Pre-election arrests intensify. Reports sent in from Krakow and Poznań]; "Natężenie aresztów trwa. Wiadomości z województw: lubelskiego, łódzkiego,

\footnotetext{
${ }^{23}$ APP, WUKPPiW, ref. no. 143, Ingerencje dotyczące gazety "Polska Ludowa", 1. 6.

${ }^{24}$ Ibidem, 1. 4.

${ }^{25}$ Ibidem, 1. 8.
} 
kieleckiego i innych" [Intensified arrests continue. Reports from voivodships: Lubelskie, Łódzkie, Kieleckie, etc.], "Terror wyborczy szaleje" [Electoral terror rages on], "Gwałty wyborcze dochodzą szczytów" [Electoral violations reach their peak], or "U.B. torturuje Polaków. Przeszło 100 kandydatów na posłów PSL w więzieniu" [UB (Secret Service) tortures Poles. Over 100 candidates for the PSL deputies in prison $]^{26}$. For the institution regulating the contents it was insignificant whether a given article was an expression of a journalist's opinion or, an attempt to reprint the official statement by the PSL authorities ${ }^{27}$. Censorship also removed content suggesting even indirectly the existence of repressions. One example of such a report was an article submitted for "Polska Ludowa" in the latter half of November 1946 which anticipated an intensification of the political conflict between the peasant movement and the bloc parties. WUKPPiW officers decided to remove from the text sections anticipating the intensification of the pre-election struggles ${ }^{28}$ even though no specific examples were provided. With time, censorship began to halt all expressions which utilised metaphors associated with struggle or fight.

During the press campaigns prior to the referendum and the election to the Legislative Sejm, the PSL periodical was more likely to receive interventions into texts regarding repressions or the voting procedure than into texts promoting the position and candidates of the PSL. However, censor activity reports include material indicating instances of blocking content which was in no way aimed against the bloc parties and their removal was presumably meant only to hinder campaign efforts. One example was the ban on publishing a complete list of names of PSL candidates running for Sejm deputies ${ }^{29}$. A special example of censors's limiting the campaign activities of the PSL was the removal of information regarding rallies organised by the PSL, for example, fragments indicating high attendance during such events ${ }^{30}$.

Another stage of censorship's activities towards the content published by the PSL periodicals started after the execution of both acts of voting. After the referendum as well as the election, censors' main task was to block any information which might have indicated forging votes. Journalists associated with the peasant movement attempted to convey that information using various forms of press releases. Original articles usually did not include any remarks indicating any direct

\footnotetext{
${ }^{26}$ AAN, GUKPPiW, ref. no. 3, folder 1/4 - "Gazeta Ludowa", 1. 43; 1. 50; 1. 52; 1. 54; 1. 61; AAN, GUKPPiW, ref. no. 3, folder 1/17 - "Gazeta Ludowa", 1. 9.

${ }^{27}$ For example, from an article prepared by the "Polska Ludowa" editorial board, censors removed one of nine resolutions of the Chief Council of the PSL; APP, WUKPPiW, ref. no. 141, Ingerencje dotyczące gazety "Polska Ludowa", 1. 66.

${ }^{28}$ APP, WUKPPiW, ref. no. 142, Ingerencje dotyczące gazety "Polska Ludowa", 1. 51.

${ }^{29}$ K. Bagiński, Cenzura ..., p. 8.

${ }^{30}$ AAN, GUKPPiW, ref. no. 3, folder 1/3: "Gazeta Ludowa", 1. 71.
} 
and specific examples of polling fraud. Neither did those include any phrases related to "forging". They attempted to publish that content mainly by describing or quoting official resolutions of the authorities of the PSL ${ }^{31}$. Another method was to quote the statements of the PSL leadership ${ }^{32}$. Neither of the methods did, however, offer the expected results.

In original articles journalists from the PSL newspapers did not formulate any direct accusations and sought expressions which in an allusive manner suggested that irregularities occurred. One such attempt at trying to "by-pass" censorship were the deliberations regarding the time it took to count the ballots after the referendum. As it was noted in one of the articles, first partial data from the people's poll from large districts such as Krakow were announced and only a few days later from much small districts ${ }^{33}$. Those remarks, though insignificant at first glance, were consistently removed from the periodicals ${ }^{34}$. The use of such a form could had been a result of two factors. First, the journalists already possessed some experience in contacts with censorship and could expect that such content would be blocked consistently. Second, in less than six months after the referendum in Poland the Secret Service (UB) commenced an operation targeting persons responsible for the PSL's communication policy, arresting, e.g. Zygmunt Augustyński, editor-in-chief of "Gazeta ludowa" ${ }^{35}$. Such actions must have had an influence on the attitudes of the journalists working in the PSL periodicals.

\section{Conclusion}

The Polish People's Party, being a legally operating political party in postWWII Poland, officially possessed the ability to conduct information and press activities. In reality, though, through restrictive activities of preventive censorship, the PSL was not able to propagate via press any communication which clashed with the interest of the PPR. It was particularly visible in reports of censor interventions made in articles devoted to the people's vote or the election to the

\footnotetext{
${ }^{31}$ APP, WUKPPiW, ref. no. 143, Ingerencje dotyczące gazety "Polska Ludowa", 1. 15.

32 AAN, GUKPPiW, ref. no. 3, folder 1/5: "Gazeta Ludowa", 1. 95.

${ }^{33}$ APP, WUKPPiW, ref. no. 141, Ingerencje dotyczące gazety "Polska Ludowa", 1. 84.

${ }^{34}$ It is possible that the removal of the article was also caused by the author's use of the example of Cracow. In that city there was a strong Municipal Association of the PSL thanks to which, unlike in the majority of district and regional people's vote committees established throughout Poland, those in Cracow did include representatives of the PSL. Since the results from Cracow diverged from the results in other large cities, in August 1946 the PPR and the PPS commenced a press campaign discrediting the voters from that city.

${ }^{35}$ To learn more about the arrests of PSL journalists see P. Swacha, Polityka informacyjna..., pp. 79-80.
} 
Legislative Sejm. According to the intention of the PPR leadership, a high result of the bloc parties was to constitute a basis for legitimising the "new rule" and facilitate the process of eliminating the opposition from the official political life.

The results of an analysis of the interventions in articles prepared by PSL activists about the referendum or the election to the Sejm indicate that the main intention of the authorities was to limit the propagation of any information regarding three areas. The first one applied to the repressions and terror which the PSL activists suffered. The second applied to the irregularities in preparing both acts of voting. The third was an attempt to inform the public about the committed forgeries. Considering the propaganda communication which accompanied the announcement of the official forged results of the referendum and the election, one must notice a close cooperation between censorship and the party-state propaganda. In that context, the task of censorship was to eliminate any communication that might have disrupted the creation of the image of the course of both events.

\section{Bibliography}

AAN (Archives of New Records), GUKPPiW, ref. no. 3.

Annex 19: "Do Generalnego Komisarza Wyborczego", in: Dokumenty fatszerstw wyborczych w Polsce w roku 1947. Drugi memoriat Polskiego Stronnictwa Ludowego w sprawie wyborów w Polsce złożony z załącznikami w dniu 1811947 roku Ambasadorom Stanów Zjednoczonych, Wielkiej Brytanii i Związu Radzieckiego w Warszawie, M. Adamczyk and J. Gmitruk (eds.), Muzeum Historii Polskiego Ruchu Ludowego, Warsaw 2002.

APP (The State Archive in Poznań), WUKPPiW, ref. no. 141, 142, 143.

Archiwum Zakładu Historii Ruchu Ludowego, PSL 1945-1949, ref. no. 64.

Buczek Roman, Stanisław Mikołajczyk, vol. 2, Century Publ. Co, Toronto 1996.

Földesi Margit, Szerencsés Károly, Historyczna rola partii chłopskich na Węgrzech po II wojnie światowej, in: Dzieje partii i stronnictw chłopskich w Europie, vol. 2 W podzielonej Europie, Akademia Humanistyczna im. A. Gieysztora, Ludowe Towarzystwo Naukowo-Kulturalne, Muzeum Historii Polskiego Ruchu Ludowego, Pułtusk-Warsaw 2007, pp. 123-130.

Kamińska Kamila, Początki cenzury, in: Zwrot polityczny' 48. Między polska droga a projektem uniwersalnym, M. Jabłonowski, W. Jakubowski, A. Krawczak (eds.), Oficyna Wydawnicza ASPRA-JR, Warsaw 2013, pp. 225-235.

Komunikat z konferencji szefów rządów Trzech Wielkich Mocarstw, tzw. Konferencji Krymskiej, in: Historia powszechna 1919-1991. Wybór tekstów źródłowych, L. Mularska-Andziak (ed.), Wydawnictwo WSH, Pułtusk 1997, pp. 92-100.

Komunikaty Polskiego Stronnictwa Ludowego 1946-1947, M. Adamczyk, J. Gmitruk, J. Mazurek (eds.), Muzeum Historii Polskiego Ruchu Ludowego, Warsaw 2002.

Referendum z 30 czerwca 1946 r. Przebieg i wyniki, A. Paczkowski (ed.), ISP PAN, Warsaw 1993.

Kubicka Grażyna, Czasopisma regionalne ruchu ludowego w latach 1944-1949, "Kwartalnik Historii Prasy Polskiej” 1986, issue 3, pp. 99-115.

Paszkiewicz Lilla, "Gazeta ludowa”. Próba walki o wolność myśli i słowa, Wydawnictwo Adam Marszałek, Toruń 2007. 
Skoczylas Michał, Wybory do Sejmu Ustawodawczego z 19 stycznia 1947 r. w świetle skarg ludności, Wydawnictwo TRIO, Warsaw 2003.

Skrzyński Tomasz. "Wejście” do ZSL. Miejsce na scenie politycznej i losy "Odrodzonego" Polskiego Stronnictwa Ludowego w 1948 i 1949 r., in: Wieś i ruch ludowy w Polsce i Europie, vol. $1 \mathrm{~W}$ kręgu historii i tradycji, J. Gmitruk, A. Indraszczyk (eds.), Muzeum Historii Polskiego Ruchu Ludowego, Wydział Nauk Humanistycznych SGGW, Ludowe Towarzystwo Naukowo-Kulturalne, Warsaw 2012, pp. 533-546.

Stępień Stanisław, Prasa ludowa w Polsce. Zarys historyczny, Wydawnictwo Prasa ZSL, Warsaw 1984.

Swacha Piotr, Polityka informacyjna Polskiego Stronnictwa Ludowego (1945-1947), Oficyna Wydawnicza ASPRA-JR, Warsaw 2010.

Swacha Piotr, Polskie Stronnictwo Ludowe w Wielkopolsce (1945-1947), "Społeczeństwo i Polityka” 2011, issue 4, pp. 24-39.

Turkowski Romuald, PSL w obronie demokracji 1945-1949, Warsaw 1992.

Ustawa z dnia 27 kwietnia 1946 r. o głosowaniu ludowym, Dziennik Ustaw RP, 10 May 1946, no. 15. Wrona Janusz, Jedni głosuja a drudzy obliczaja głosy: wybory do Sejmu Ustawodawczego RP w 1947 r., „Annales Universitatis Mariae Curie-Skłodowska. Sectio F. Historia” 1997/1998, vol. LII/LIII, pp. 343-482.

Piotr Swacha

\section{Censorship in the PSL Press within the Period of the 1946 Referendum and the Legislative Sejm Election}

\section{(Summary)}

The main goal of the article is to analyse censorship interventions made in articles raising the topics of the referendum and the election to the Legislative Sejm which were prepared for print in the periodicals of the Polish People's Party. The material developed by the Main Office of Control of Press, Publications and Shows in Warsaw and by its regional divisions constituted its basic source of information. I conducted a quantitative analysis of the interventions using a sample of the reports of the censorship institution regarding the "Polska Ludowa" periodical. I have also discussed the content removed from print. Within the studied area, censorship most often prevented the PSL periodicals from publishing information regarding the repressions of the PSL's activists, informing about the organisation of both events and suggesting the fact of forging votes.

Keywords: "Polska Ludowa", Polish People's Party, PSL periodicals, Main Office of Control of Press, Publications and Shows in Warsaw, censorship after 1945 